\title{
KAJIAN PEMANFAATAN POTENSI SUMBERDAYA AIR DI KABUPATEN PANDEGLANG
}

\section{Study of the Potential Utilization Water Resources in Pandeglang}

\author{
Hendra Tjahjono, Kusno Wibowo dan Wage Komarawidjaja \\ Pusat Teknologi Lingkungan \\ Badan Pengkajian dan Penerapan Teknologi , \\ Jalan M.H. Thamrin No. 8 Jakarta 10340 \\ Hendra_tjahjono56@yahoo.com \\ Diterima : 8 Juni 2012; Revisi : 18 Juni 2012; Disetujui : 26 Jni 2012
}

\begin{abstract}
Water, both ground water and surface water is the source of life that can not be replaced by anything and without water, people, animals and plants will not be able to live. But in its utilization, there are still many who are not as intended or use to beyond the limit, so that on one hand many are wasted in vain, but on the other side of the many in need. Use of water during the last decade has increased due to several factors, among others, by human activities increasingly varied, the number of population increases, the amount of water for human needs has also increased and this contributes to water quality. It also affects the limitations of water and natural conditions. It required a water management system is very good with attention to natural condition sand the availability of water in order to reach an appropriate management of the water governance and the availability of clean wateris needed.
\end{abstract}

Keywords: water, water management, environment

\begin{abstract}
Abstrak
Air, baik air tanah maupun air permukaan merupakan sumber kehidupan yang tidak dapat tergantikan oleh apa pun dan tanpa air, manusia, hewan dan tanaman tidak akan dapat hidup terutama sebagai air minum. Tetapi dalam pemanfaatannya, masih banyak yang tidak sesuai dengan peruntukannya ataupun mempergunakan sampai diluar batas, sehingga disatu sisi banyak yang terbuang dengan sia-sia tetapi dilain sisi banyak yang membutuhkan. Penggunaan air selama dasa warsa terakhir ini meningkat disebabkan oleh beberapa faktor, antara lain oleh kegiatan manusia yang semakin bervariasi, pertambahan jumlah penduduk yang meningkat, maka jumlah air untuk kebutuhan manusia juga meningkat dan hal ini berpengaruh terhadap kualitas air. Selain itu juga berpengaruh terhadap keterbatasan air dan kondisi alam. Untuk itu diperlukan suatu system pengelolaan air yang sangat baik dengan memperhatikan akan kondisi alam dan ketersediaan akan air sehingga tercapai suatu pengelolaan yang sesuai dengan tata kelola air.
\end{abstract}

Kata kunci : air, pengelolaan air, lingkungan

\section{PENDAHULUAN}

Salah satu kebutuhan manusia yang paling vital adalah air, karena air merupakan sumber kehidupan yang tidak dapat tergantikan oleh apa pun dan tanpa air, manusia, hewan dan tanaman tidak akan dapat hidup. Selain itu, air juga banyak sekali manfaatnya dan kegunaannya diantaranya untuk mandi, cuci dan yang terpenting adalah untuk minum. Wilayah Indonesia memiliki 6\% dari persediaan air dunia atau sekitar 21\% persediaan air di Asia Pasifik. Namun untuk mendapatkan air bersih dan layak pakai masih sulit serta dalam pemanfaatannya, masih banyak yang tidak sesuai dengan peruntukannya ataupun mempergunakan sampai diluar batas, sehingga disatu sisi banyak yang terbuang dengan sia-sia tetapi dilain sisi banyak yang membutuhkan. Air di bumi dapat digolongkan menjadi dua, yaitu :

Air Tanah : adalah air yang berada di bawah permukaan tanah. Air tanah dapat dibagi menjadi dua, yakni : Air Tanah Preatis : air tanah yang letaknya tidak jauh dari permukaan tanah serta berada di atas lapisan kedap air/ impermeable. Air Tanah Artesis : air tanah yang letaknya sangat jauh di dalam tanah serta berada diantara dua lapisan kedap air.

Air pemukaan adalah air yang berada di permukaan tanah dan dapat dengan mudah 
dilihat oleh mata kita. Contoh air permukaan seperti laut, sungai, danau, kali, rawa, empang, dan lain sebagainya. Air permukaan dapat dibedakan menjadi dua jenis yaitu :Perairan Darat : adalah air permukaan yang berada di atas daratan misalnya seperti rawa-rawa, danau, sungai, dan lain sebagainya. Peariran Laut : adalah air permukaan yang berada di lautan luas. Contohnya seperti air laut yang berada di laut.

Dari penggunaan air selama dasa warsa terakhir ini meningkat dengan tajam. Hal ini disebabkan oleh beberapa faktor, antara lain oleh kegiatan manusia yang semakin bervariasi sehingga kebutuhan akan air meningkat. Selain itu juga dengan pertambahan jumlah penduduk yang meningkat, maka jumlah air untuk kebutuhan manusia juga meningkat[1].

Tabel 1 Jumlah Penduduk Kabupaten Pandeglang per Kecamatan

\begin{tabular}{|c|c|c|}
\hline Kecamatan & Pria & Wenita \\
\hline$\langle 1\}$ & (2) & (3) \\
\hline [001] Sumur & 11.531 & 11.151 \\
\hline [O02] Cimanggu & 18.547 & 18.093 \\
\hline [003] Cibalung & 14.899 & 13.895 \\
\hline [004] Cibitung & 10.837 & 10.330 \\
\hline [005] Cikeusik & 26.225 & 24.852 \\
\hline [006] Cigeulis & 17.360 & 16.465 \\
\hline [O07] Parimbang & 25.056 & 23.828 \\
\hline [008] Sobang & 17.687 & 17.338 \\
\hline [009] Murvul & 11.328 & 10.796 \\
\hline [010] Angsana & 13.224 & 12.336 \\
\hline [011] Sindangresmi & 10.787 & 10.554 \\
\hline [012] Ploung & 17.822 & 17.291 \\
\hline [013] Bojong & 17.201 & 16.488 \\
\hline [014] Saketi & 21.773 & 21.161 \\
\hline [015] Cisata & 11.860 & 11.476 \\
\hline [016] Pagalaran & 17.391 & 16.509 \\
\hline [017] Patia & 13.874 & 13.406 \\
\hline [018] Sukaresmi & 17.402 & 16.367 \\
\hline [019] Labuan & 27973 & 25.866 \\
\hline [020] Carita & 16.489 & 15.523 \\
\hline [021] Jiput & 14.423 & 13.968 \\
\hline [022] Cikedal & 15.377 & 15.058 \\
\hline [023] Menes & 17.907 & 17.415 \\
\hline [024] Pulosan & 14.103 & 13.411 \\
\hline [025] Mandalawangi & 23.550 & 22.710 \\
\hline [026] Cimanuk & 19.537 & 18.663 \\
\hline [027] Cipeuceng & 14.383 & 13.493 \\
\hline [028] Barjar & 15.099 & 14.671 \\
\hline [029] Kaduhejo & 17.617 & 16.910 \\
\hline [030] Mekarjaya & 9.514 & 9.350 \\
\hline [031] Pandeglang & 20.592 & 19.054 \\
\hline [032] Majesani & 22.968 & 21.619 \\
\hline [033] Cadasan & 16.443 & 14.881 \\
\hline [034] Karangtanjung & 16.860 & 15.467 \\
\hline [035] Koronoang & 9.230 & 8.488 \\
\hline $\begin{array}{l}\text { Kabupaten } \\
\text { Pandeglang }\end{array}$ & 586.869 & 558.923 \\
\hline
\end{tabular}

Sumber : Panddeglang Dalam Angka 2010
Seperti disebutkan di atas bahwa dengan keragaman atau bervariasinya kegiatan manusia yang menyebabkan kebutuhan air juga bervariasi, maka hal ini juga berpengaruh terhadap perubahan kualitas dan kuantitas air yang dipergunakan. Hal ini dapat dilihat dengan banyaknya permintaan akan air dengan kualitas yang baik, misalnya untuk kegiatan yang berhubungan dengan produksi makanan dan minuman. Hal ini akan berpengaruh besar terhadap produk yang dihasilkan, semakin baik airnya maka produk yang dihasilkan juga baik begitu pula sebaliknya.

Akan tetapi kebutuhan akan air tersebut tidak disesuaikan dengan jumlah persedian air, baik air tanah ataupun air permukaan, sehingga akan berpengaruh besar terhadap kondisi alam dengan menurunnya ketersediaan air. Hal ini lebih diperparah lagi dengan perubahan musim yang tidak menentu dan perubahan Daerah Aliran Sungai (DAS) yang telah di konversi. Kondisi kekritisan air sungai dapat dinilai dari fluktuasi debit air maksimum dan minimum. Ternyata fluktuasi debit air maksimum dan minimum pada beberapa sungai di Jawa Barat telah melampaui angka 100 m3/detik, seperti pada table berikut[2].

Dari tabel terlihat bahwa fluktuasi debit air sudah melewati 100 m3/det, hal ini akan berakibat banyak terjadi pencemaran terhadap air permukaan terutama sekali DAS dan menurunkan kualitas air sungai yang selama ini paling banyak dimanfaatkan oleh manusia. Dari pemantauan kualitas air yang dilakukan di 30 sungai di Indonesia pada tahun 2005 menunjukkan lebih dari $50 \%$ parameter yang dipantau (DO, BOD, COD, coli, dan total coliform) sudah tidak memenuhi criteria mutu air kelas II PP 82 Tahun 2001[5,8].

Adapun tujuan penelitian ini adalah untuk melestarikan lingkungan dari sisi tata air dengan mempertahankan kondisi daerah aliran sungai (DAS) dengan cara menjaga keseimbangan tata air, serta membangun konsep permodelan pengelolaan sumberdaya air berbasis daerah aliran sungai (DAS) .

Tabel 2. Debit Air di Beberapa Sungai di Jawa Barat - Tahun 2004 - 2005

\begin{tabular}{llccccc}
\hline No & Sungai & Loksai & \multicolumn{2}{c}{$\begin{array}{c}\text { Q 2004 } \\
\text { (m3/det) }\end{array}$} & \multicolumn{2}{c}{$\begin{array}{c}\text { Q 2005 } \\
\text { (m3/det) }\end{array}$} \\
\hline & & & Maks & Min & Maks & Min \\
1 & Citarum & Jabar & -- & -- & 240 & 10 \\
2 & Cimanuk & Jabar & 1000 & 4 & 1000 & 4 \\
3 & Ciliwung & Jabar & -- & -- & 570 & 4 \\
4 & Bekasi & Jabar & -- & -- & 775 & 5 \\
5 & Cisadane & Jabar & -- & -- & 1600 & 9 \\
6 & Citanduy & Jabar & -- & -- & 1757 & 4 \\
\hline
\end{tabular}

Sumber : Ditjen Sumberdaya Air, Dep. PU, 2005[8] 


\section{BAHAN DAN METODE}

Kegiatan ini mengambil lokasi di Kabupaten Pandeglang sebagai studi kasusnya dengan metodologi berdasarkan data yang didapat, yaitu data sekunder dengan cara pengumpulan data dari instansi terkait (Pemda setempat ataupun pengelolan air) serta data primer yaitu dengan melakukan wawancara langsung kepada pengguna air ataupun pengelola dengan cara pengisian kuesioner. Selain itu diperlukan juga data pendukung seperti data penduduk di lokasi, peta lokasi (peta administrasi dan peta penyebaran penduduk dan fasilitas lain , peta topografi) serta data kebutuhan akan air. Dengan menganalisa data-data yang didapat, dapat diketahui suatu sistem pengelolaan sumberdaya air di daerah tersebut yang kemudian akan direkomendasikan atau diusulkan konsep permodelan dan cara terbaik dalam pengelolaan sumberdaya air.

Jadi secara garis besar, lingkup kegiatan ini dapat disampaikan sebagai berikut:

- Melakukan kajian geologi dan hidrogeologi

- Melakukan survey cepat untuk mendapatkan data kebutuhan air dan data sumur penduduk.

- Penyusunan konsep permodelan

- Menyusun rekomendasi atas keluaran permodelan

\section{HASIL DAN PEMBAHASAN}

\subsection{Data Observasi dan Survai}

Seperti diketahui bahwa air adalah sumber kehidupan yang sangat vital bagi mahluk hidup dan air ini bisa diperoleh dari air tanah dalam maupun air dangkal atau air permukaan. Air pemukaan adalah air yang berada di permukaan tanah dan dapat dengan mudah dilihat oleh mata kita. Contoh air permukaan seperti laut, sungai, danau, kali, rawa, empang, dan lain sebagainya. Selain itu masyarakat kabupaten Pandeglang banyak yang mengandalkan air hujan yang dipergunakan untuk mandi dan cuci. Ada pula yang menampung air hujan dan kemudian dimanfaatkan untukairminum.

Hujan merupakan salah satu sumber air permukaan dan untuk Kabupaten Pandeglang mempunyai jumlah curah hujan yang beragam menurut bulan dan letak pos pengamatan. Rata-rata curah hujan selama tahun 2009 berkisar antara 175,10 mm (Cimanggu) sampai $317,82 \mathrm{~m}$ (Jiput). Data curah hujan dapat dilihat pada peta curah hujan berikut [1].

Dalam pelaksanaan kegiatan ini mengambil kasus di Kabupaten Pandeglang. Kabupaten Pandeglang merupakan salah satu kabupaten di provinsi Banten yang masuk dalam DAS Ciujung.

Alasan mengapa diambil kasus adalah kabupaten Pandeglang, karena di kabupaten ini masih sangat sulit akan air bersih terutama pada musim kemarau, seperti daerah Cigeulis. Sedang pada daerah lain seperti Panimbang, Tanjung Lesung, air sudah terkena intrusi air laut sehingga ,menjadi payau.

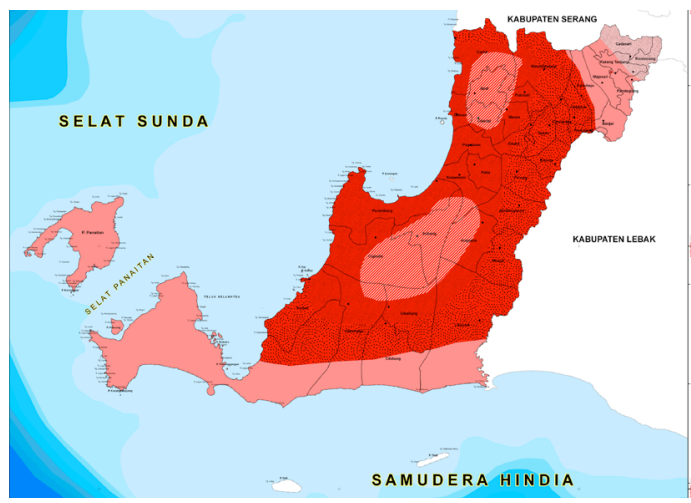

Gambar 1. Peta Curah Hujan di Kabupaten Pandeglang

Di Indonesia saat ini terdapat 5.950 daerah aliran sungai (DAS). Sungai menurut jumlah airnya diklasifikasikan sebagai (a) sungai permanen, (b) sungai periodik, (c) sungai intermittent, dan (d) sungai ephemeral. Pengklasifikasian sungai lainnya dilakukan menurut asal airnya, yaitu (a) sungai mata air, (b) sungai air hujan, (c) sungai pencairan es/salju, dan (d) sungai campuran.

Untuk tahap awal, adalah studi literature dan kontak dengan instansi yang akan bekerjasama. Targetnya adalah daerah aliran sungai, dimana lokasi daerah dapat berupa gabungan dari lebih dari satu kabupaten dan telah ditetapkan yaitu kota Pandegelang, Serang - Propinsi Jawa Barat dengan outcome adalah diterapkannya konsep pengelolaan yang akan dibangun di beberapa daerah sasaran, sehingga kerangka pengelolaan sumberdaya air dapat terarah menuju pada pengelolaan lingkungan yang berkelanjutan.

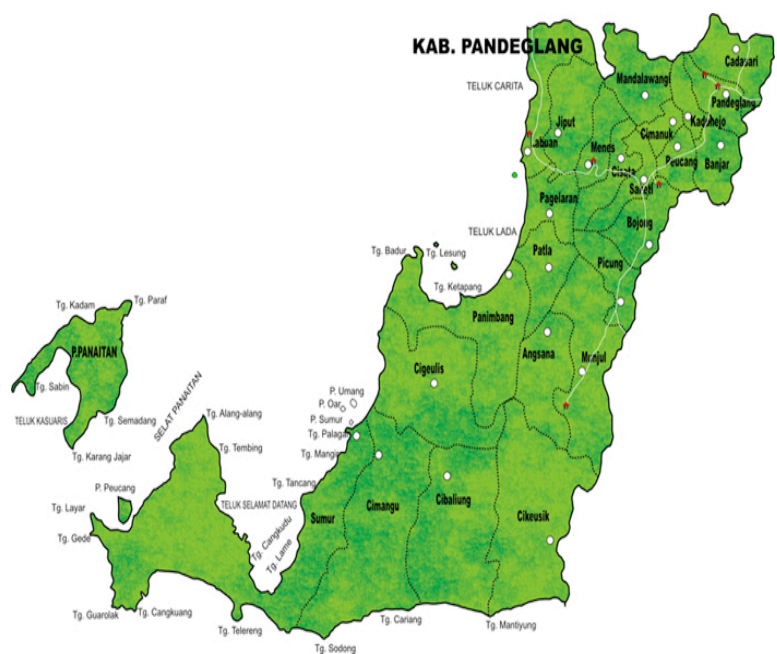

Gambar 2. Peta Administrasi Kabupaten Pandeglang 
Adapun urutan kegiatan adalah sebagai berikut:

- Proses identifikasi : pengumpulan data, fakta dan studi literatur.

- Analisis data

- Membangun model

Melakukan simulasi model. Dalam penanganan masalah air bersih ini telah dibuat suatu Model Sistem Penanggulangan Permasalahan Air Bersih yang salah satunya adalah memanfaatkan air hujan. Secara singkat dapat dijelaskan sebagai berikut [3] :

- Air hujan secara manual diinjeksikan kedalam akuifer (air tanah dangkal/artesis) yang merepresentasikan imbuhan buatan yang ditujukan untuk mengembalikan tinggi tekan (untuk air tanah artesis) dan tinggi muka air tanah (untuk air tanah dangkal).

- Simulasi model air tanah ini kemudian menyajikan dampak yang ditimbulkan akibat imbuhan buatan tersebut.

- Penyajian dampak ini dapat berupa grafik, ataupun gambar visualisasi kondisi air tanah baik sebelum dilakukan imbuhan dan setelah dilakukan imbuhan.

Skenario jumlah, lokasi sumur, dan besaran imbuhan yang bersamaan dengan ekstraksi air tanah akan disimulasikan didalam permodelan air tanah ini hingga mendapatkan kondisi yang optimal dalam keseimbangan tata air tanah di lokasi kawasan target. Selain itu, seluruh informasi yang akan menunjang permodelan ini, baik untuk input data maupun untuk penyusunan model rencananya akan diperolah dengan melakukan survey pendataan sekunder yang berasal dari instansi lokal terkait maupun masyarakat setempat (dengan melakukan wawancara sesuai dengan kebutuhan) maupun instansi lainnya sesuai dengan substansial kebutuhannya (Instansi yang menangani pemetaan maupun data geologi/geohidrologi, dan sebagainya)

Dari studi literatur, dapat diketahui informasi mengenai penanganan dan pengelolaan air yang pernah dilakukan dan ini dapat dipergunakan sebagai acuan dalam pelaksanaan di lapangan.

\subsection{Kondisi Hidrogeologi Pandeglang}

Kondisi hidrogeologi yang terlihat adalah bahwa dikawasan Pandeglang terdapat potensi air tanah yang mempunyai produktivitas yang bervariasi, dari yang rendah hingga produktivitas tinggi. Dikawasan selatan dan di tengah Kabupaten Pandeglang, mempunyai akuifer dengan air tanah langka. Hanya sebagian kawasan kecil yang mempunyai akuifer dengan produktivitas sedang dengan penyebaran yang terbatas, yakni didaerah pesisir barat. Akuifer disini mempunyai produktivitas sedang tapi tidak menerus. Di kawasan tengah-selatan, dikawasan ini akuifer mempunyai potensi air tanah sedang dan bersifat lokal, sehingga pengaruh perubahan iklim dan cuaca sangat signifikan. Potensi air tanah dengan produktivitas yang tinggi dan dengan luasnya tersebar terdapat dibagian utara Kabupaten Pandeglang[1].

Bila dilihat dari gambar 5, maka dapat diketahui aliran air tanah lebih banyak kearah lebih rendah yaitu di bagian utara kabupaten Pandeglang, sedangkan di bagian selatan sangat sulit atau langka akan air.

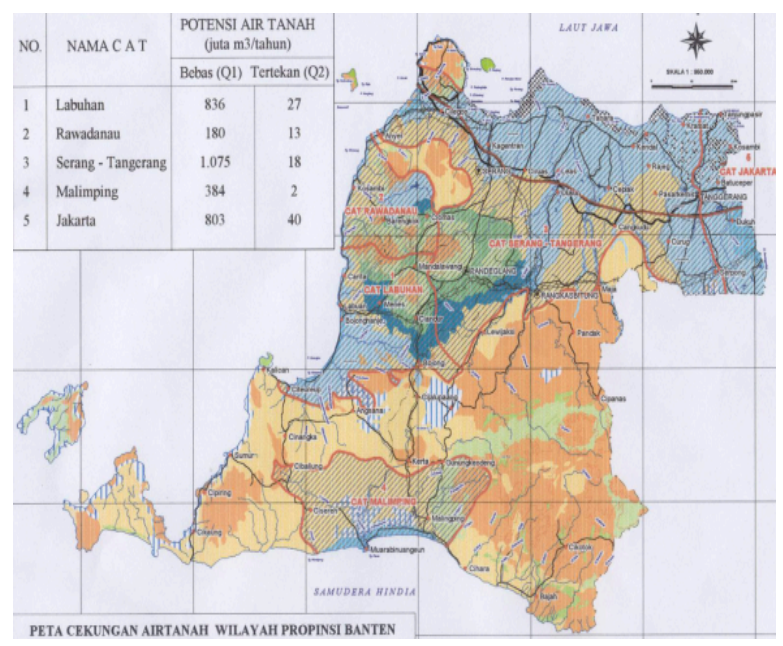

Gambar 3. Peta Hidrogeologi Kabupaten Pandeglang dan sekitarnya

\subsection{Pemantauan Sumur Penduduk}

Data hasil pemantauan sumur penduduk disekitar Kecamatan Panimbang, Kecamatan Cigeulis, Kecamatan Munjul dan Kecamatan Pagelaran, menunjukkan karakteristik air tanah yang sama. Sesuai dengan peta hidrogeologi, karakteristik akuifer di kawasan ini memungkinkan untuk menyimpan air tanah.

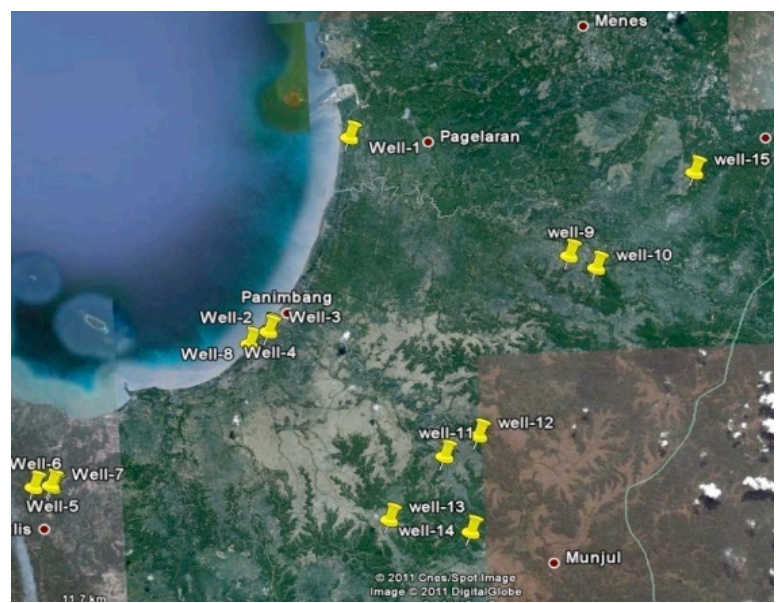

Gambar 4. Peta Sebaran lokasi pemantauan sumur penduduk 


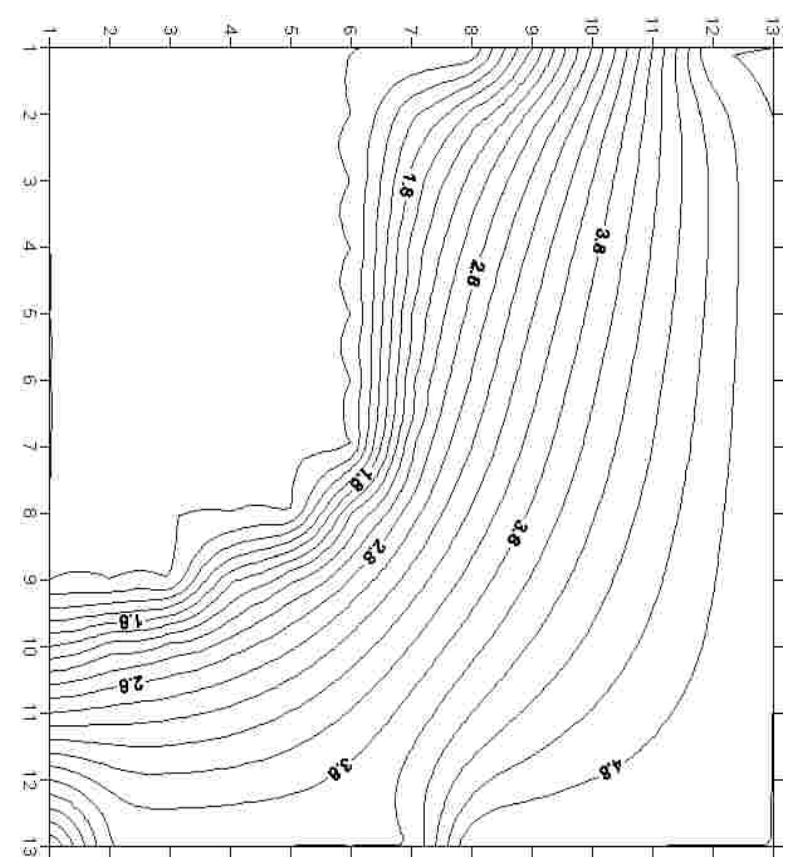

Gambar 5. Kontur muka air tanah dangkal

Distribusi muka air tanah dapat dilihat seperti pada gambar 5 yang memperlihatkan kontur muka .

Dengan melihat distribusi tersebut dengan jumlah air yang tidak merata, maka dapat dilakukan suatu cara yaitu dengan injeksi air tanah melalui air hujan. Adapun tujuan dari dilakukan injeksi air yaitu untuk menambah kandungan air yang ada di dalam tanah dengan memanfaatkan air hujan sebagai air injeksi. Untuk itu perlu dilakukan simulasi permodelan injeksi air tersebut[4,6].

\subsection{Hasil Simulasi Permodelan}

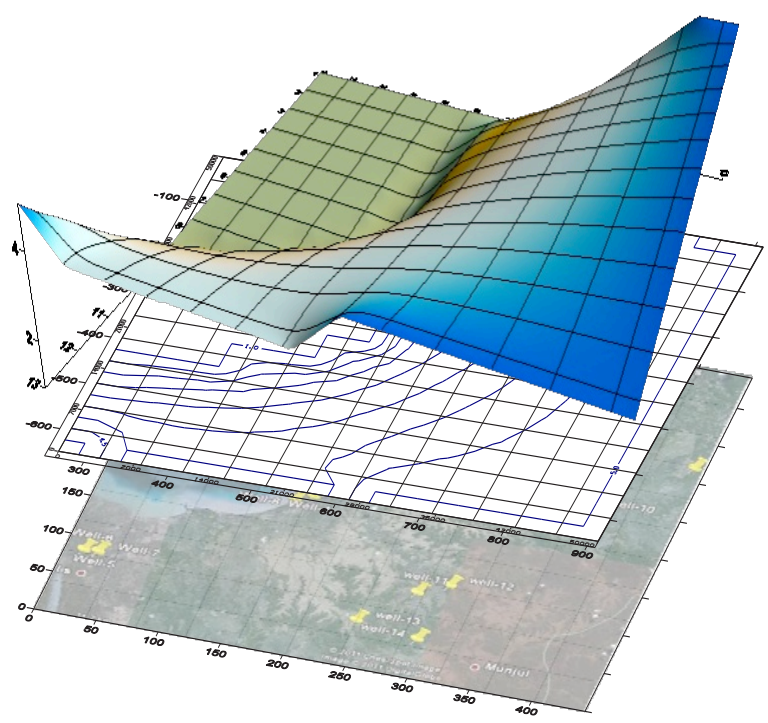

Gambar 6. Kondisi muka air tanah sebelum Penambahanair hujan[3,4]

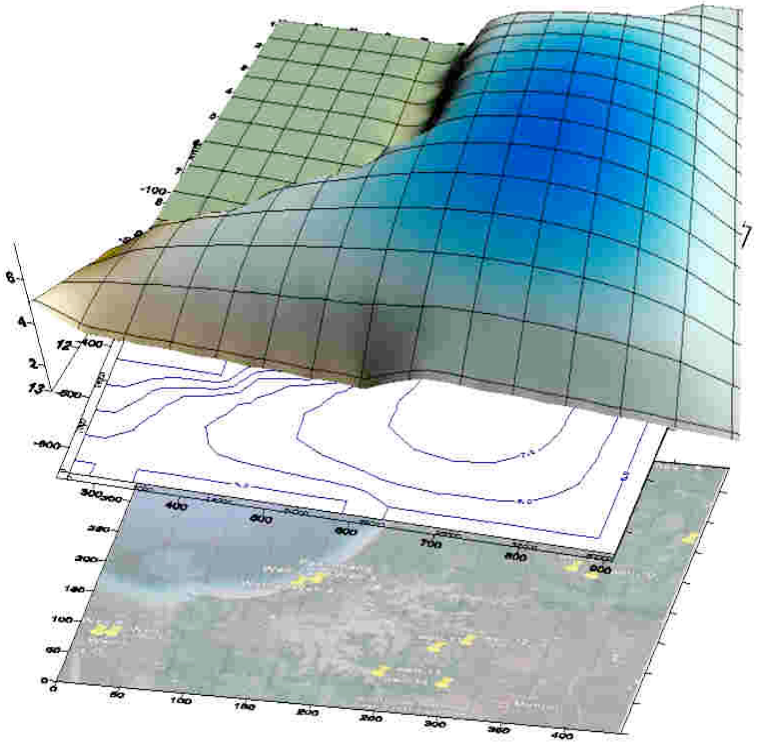

Gambar 7. Kondisi Air Tanah Setelah Penambahan air hujan[3,4].

Kualitas air dapat berubah sesuai interaksinya dengan kondisi lingkungan dan kegiatan di sekitarnya. Beberapa penyebab perubahan kualitas air adalah[7,9]:

1. Masuknya materi; masukan materi polutan ke dalam air permukaan selalu menyebabkan perubahan kualitas air.

2. Asupan panas; biasanya disebabkan oleh aliran buangan air limbah dari sumber -sumber pertukaran panas. Asupan panas sudah tentu akan meningkatkan suhu air.

3. Pengambilan air; biasanya untuk kepentingan pengolahan air bersih, baik bagi kepentingan umum maupun untuk kepentingan aktivitas industri. Pengambilan air akan mengakibatkan jumlah air berkurang sehingga kemampuan pengenceran dari suatu badan air akan berkurang. Konsekuensinya, polutan akan terakumulasi dalam air yang lebih sedikit.

4. Perubahan pola aliran; misalnya akibat pembuatan bendungan, penambahan alat dan bangunan air, pembangunan kanal, dan sebagainya.

5. Perubahan morfologi badan air; misalnya akibat normalisasi tepi sungai, pengerukan dasar sungai, pengerasan dasar sungai, dan sebagainya.

6. Interaksi kehidupan flora dan fauna; misalnya akibat pembusukan ganggang dalam jumlah yang sangat besar.

Gambar (a) dan Gambar (b) menunjukkan: Kondisi awal (sebelum imbuhan dan implementasi imbuhan 10.500.000 m3 air hujan. 


\section{KESIMPULAN}

Pemanfaatan air dalam kehidupan manusia sesuai dengan peruntukannya dan sesuai dengan tata kelola air diharapkan dapat menjadi salah satu alternatif dalam pengelolaan air terutama air permukaan. Sebagai konsekuensinya, maka dibutuhkan suatu kerjasama yang baik antara masyarakat sebagai pengguna dan pengelola air sehingga terwujud suatu sistim pengelolaan air yang baik khususnya untuk mengurangi penggunaan air yang berlebihan dan dapat mempengaruhi ketersediaan air. Jadi Penggunaan dan pengelolaan air di daerah/lokasi masih belum tertata dengan baik dan belum sesuai dengan tata kelola air serta Instansi terkait masih belum secara serius menangani pengelolaan air, baik air permukaan maupun air tanah.

\section{DAFTAR PUSTAKA}

1. Kabupaten Pandeglang Dalam Angka 2010.

2. Bappenas, 2009. Kajian Strategis Pengembangan Sumberdaya Air Nasional. Badan Perencanaan
Pembangunan Nasional.

3. Hadipurwo, Satryo dan Syamsu Hadi. 2000. Konservasi Air Tanah Daerah Jakarta - Bogor. Menyertai Peta Pengendalian Pengambilan Air Tanah. Direktorat Geologi Tata Lingkungan.

4. Hutasoit, Lambok M. 2004. Hidrogeologi Cekungan Jakarta untuk Pengembangan Resapan Buatan. Laboratorium Simulasi Numerik Hidrogeologi. Departemen Teknik Geologi. ITB

5. Mutu Kualitas Air Sungai di Indonesia, Kementerian Lingkungan Hidup, Tahun 2005

6. Puslitbang Teknologi Sumber Daya Air Departemen Pemukiman dan Prasarana Wilayah. 2000. Studi Banjir di Wilayah Kamal - Cengkareng - Kapuk. Propinsi DKI Jakarta.

7. Samsuhadi. 1990. Optimal Control Of Saltwater Intrusion. Application For The Jakarta Groundwater Basin. Master's Thesis. Humboldt State University. Arcata. California.

8. Debit Air sungai di Jawa Barat, Ditjen Sumberdaya Air, Dep. PU, Tahun 20

9. Technical Note Diseminasi Teknologi Efisiensi Pemanfaatan Sumberdaya Air, Heru Dwi Wahyono, 2012. 